\title{
Proton Exchange Membrane Fuel Cell Reversal: A Review
}

\author{
Congwei Qin ${ }^{1,2}$, Jue Wang ${ }^{1,2}$, Daijun Yang ${ }^{1,2}$, Bing $\mathrm{Li}^{1,2, *}$ and Cunman Zhang ${ }^{1,2, *}$ \\ 1 School of Automotive Studies, Tongji University, Shanghai 201804, China; 1434427@tongji.edu.cn (C.Q.); \\ 1410816@tongji.edu.cn (J.W.); yangdaijun@tongji.edu.cn (D.Y.) \\ 2 Clean Energy Automotive Engineering Center, Tongji University, Shanghai 201804, China \\ * Correspondence: libing210@tongji.edu.cn (B.L.); zhangcunman@tongji.edu.cn (C.Z.); \\ Tel.: +86-21-6958-3891 (B.L.); +86-21-6958-3850 (C.Z.)
}

Academic Editors: David Sebastián and Vincenzo Baglio

Received: 19 July 2016; Accepted: 10 September 2016; Published: 8 December 2016

\begin{abstract}
The $\mathrm{H}_{2}$ /air-fed proton exchange membrane fuel cell (PEMFC) has two major problems: cost and durability, which obstruct its pathway to commercialization. Cell reversal, which would create irreversible damage to the fuel cell and shorten its lifespan, is caused by reactant starvation, load change, low catalyst performance, and so on. This paper will summarize the causes, consequences, and mitigation strategies of cell reversal of PEMFC in detail. A description of potential change in the anode and cathode and the differences between local starvation and overall starvation are reviewed, which gives a framework for comprehending the origins of cell reversal. According to the root factor of cell starvation, i.e., fuel cells do not satisfy the requirements of electrons and protons of normal anode and cathode chemical reactions, we will introduce specific methods to mitigate or prevent fuel cell damage caused by cell reversal in the view of system management strategies and component material modifications. Based on a comprehensive understanding of cell reversal, it is beneficial to operate a fuel cell stack and extend its lifetime.
\end{abstract}

Keywords: PEMFC; cell reversal; starvation; mitigation strategies

\section{Introduction}

At present, the proton exchange membrane fuel cell is the most promising energy system used in commercialized electric vehicles; it has the following advantages: low-temperature operation $\left(50-100{ }^{\circ} \mathrm{C}\right)$, high power density $(40 \%-60 \%)$, nearly zero pollutants compared to conventional internal combustion gasoline vehicles, simple structure, and so on [1,2]. However, during the PEMFC technological development, there are two primary barriers to commercialization-durability and cost [3].

Cell polarity reversal occurs frequently in standard fuel cell operating conditions. In such a condition, there is some irreversible damage to fuel cell stack material, including flow field plate, membrane electrode assembly (MEA), and other constructional elements, which seriously affects the durability of PEMFC. There are two principal approaches to solving this problem. The first is a system control strategy whereby specially designed software would monitor anode and cathode outlet exhaust gas composition, cell voltage, and local density variation response. The software would then regulate fuel/air stoichiometry, cell temperature, current density, water management, and any other operating parameters to minimize fuel cell reversal damage [4-6]. Although the system control strategy can be an effective and efficient method to extend a fuel cell's lifespan, it would require a peripheral sensor to monitor and feedback information, and even to regulate the system parameters for steady operation. In fact, it does not take long for cell reversal damage to occur. The extra equipment involved would not only increase system complexity and decrease cost efficiency, but also cannot address cell reversal 
in time. Therefore, there is a second more direct strategy, system hardware material modification. Because all forms of cell reversal damage eventually lead to system material degradation, optimized materials would minimize cell reversal and improve fuel cell durability in nature. This paper presents the causes, types of damage, and improvement approaches related to cell reversal in a fuel cell.

\section{PEMFC Cell Reversal Description}

In a single fuel cell or fuel cell stack system, electrode potential drives chemical reactions, including hydrogen oxidation reaction (HOR), oxygen reduction reaction (ORR), carbon corrosion, and water electrolysis. In normal operations, there are excess hydrogen and air supplied to the anode and cathode, respectively. HOR and ORR take place in the anode and cathode, respectively, to produce sufficient amounts of electrons and protons. Nevertheless, there are many extreme operations or conditions, such as insufficient supply of reactant [5-7], low catalyst performance, uneven gas distribution, drastic current load change, and startup or shutdown operations [8], which would result in potential change. In PEMFC cell reversal, the experiment polarity curve shows that the anode potential increases and the cathode potential decreases, narrowing the electric potential difference and even reversing for several seconds. The fuel cell stack cannot work normally anymore and will consume energy instead of supplying energy. As a result, hydrogen and oxygen would be present in the wrong electrode components of fuel cell, which induces a corresponding potential change. In each cavity, all kinds of matter spontaneously recombine and react with each other to make the system right. However, because of the wrong initial conditions, the result cannot match what the fuel cell should be.

As shown in Figure 1, the fuel cell was subjected to cell reversal test experiment (hydrogen starvation). Figure 1 illustrates the time-dependent change in the anode and cathode potentials versus RHE in hydrogen starvation. The cell terminal voltage quickly changed to a negative voltage, from 1.0 to $-2.0 \mathrm{~V}$ [6]. This will be discussed in more detail in Section 3.1.1.

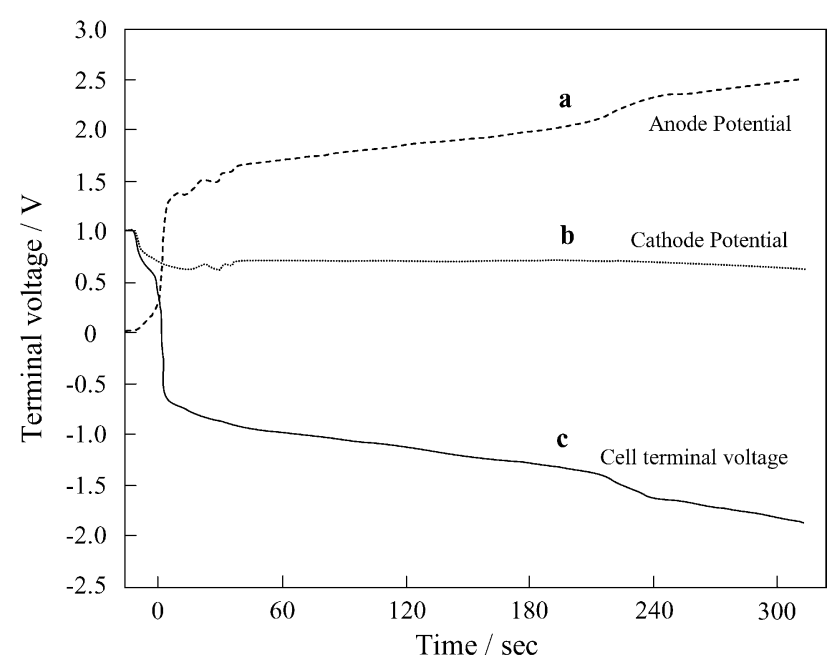

Figure 1. Anode and cathode potential change experienced cell reversal caused by hydrogen starvation. Reproduced with permission from [6]. Copyright Elsevier, 2004.

In the case of air starvation, there is another type of cell reversal detected in currency to voltage (I-V) image. In Figure 2, we can see that cell voltage decreased rapidly to become negative when the cell reversal experiment started (air starvation). After the initial drop, the anode potential, cathode potential, and cell voltage all reached constant values but remained near zero [5]. 


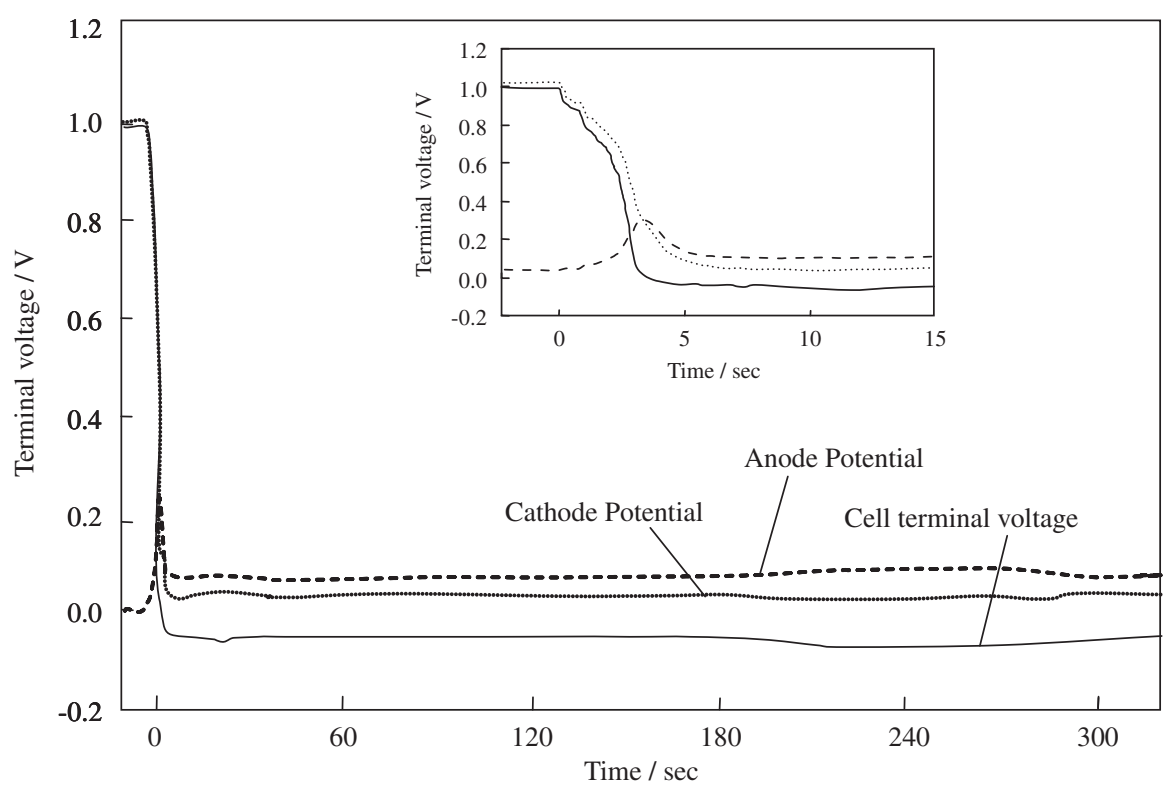

Figure 2. Anode and cathode potential change in cell reversal caused by oxygen starvation. Reproduced with permission from [5]. Copyright Elsevier, 2008.

Fuel starvation results in a markedly different level of cell reversal compared to air starvation. Cell terminal voltage is much larger with low fuel feed compared to low air feed. The damage to material under low potential is less serious than the high potential caused by hydrogen starvation. From this point, we can understand that the damage of fuel starvation could be caused by gas supply and flow field diffusion. In view of keeping reactant diffusion steady, and considering gas diffusion layer design, flow field design, and membrane gas permeation, the assembly of different layers should attract more attention. In the meantime, how to eliminate interface effect is also a point to be researched. Steadier system operation conditions will mean a longer lifetime.

Due to the carbon corrosion in cell reversal, polarity curve, gas chromatography (GC) and differential electrochemical mass spectrometry (DEMS) can be the main in situ measurements to analyze the extent of carbon corrosion, the exhaust gas compositions, and the anode or cathode outlet contents [9-11]. These techniques can realize online detection of carbon dioxide generated by carbon corrosion. After cell reversal, energy dispersive X-ray analysis (EDX), transmission electron microscopy (TEM) [6], scanning electron microscopy (SEM), X-ray diffraction (XRD), electrochemical impedance spectrum (EIS), inductively coupled plasma (ICP), and Raman Spectroscopy are the main means used to characterize the status of the catalyst layer (CL), catalyst nanoparticles sintering, and carbon corrosion extent $[10,12-15]$. These methods analyze CL morphology, catalyst distribution, elemental content, atomic structure, and impedance, respectively.

In a fuel cell reversal system experiment, there is a three-step protocol to test and categorize the electrode's reversal tolerance [16]. The point of this protocol is to build fuel starvation by replacing $\mathrm{H}_{2}$ content with humidified $\mathrm{N}_{2}$ to measure the performance of MEA after cell reversal. Specifically, Step 1, MEA should be in the condition of cell reversal for a long time, with a period of $\mathrm{H}_{2}$ supply. Step 2, MEA is in the cycle between cell reversal and normal $\mathrm{H}_{2}$ supply every $30 \mathrm{~s}$. Step 3, MEA would be in cell reversal until the cell potential is $-2.0 \mathrm{~V}$. In the whole test procedure, the anode outlet air would be measured for the concentration of $\mathrm{CO}_{2}$ and $\mathrm{O}_{2}$.

To simulate and design cell reversal experiment, sub-stoichiometric reactant feeding is the first step. Then, regulating the fuel and air ratio should take a more important place for cell reversal data image. The data collection should include I-V image, different electrode potential of time-dependent like Figures 1 and 2, localized current and potential change across the electrode plane, and so on. 


\section{Causes and Consequences of Cell Reversal}

\subsection{Causes of Cell Reversal}

The main cause of cell polarity reversal is that the fuel cell cannot satisfy the requisition of the electron and proton from the normal anode and cathode chemical reactions [17]. This key factor occurs in some improper or nonstandard operations, such as fuel and air sub-stoichiometric feeding, rapid load change, low catalyst performance, control module failure, and so on. During a sudden load change or incorrect operation, such as start-up or artificial reasons, fuel and oxidant starvation would occur. Li et al. [18] found that the cell performance loss was induced by the rapidly changing load frequencies resulting in catalyst particles' growth and agglomeration in the anode. This is a typical example where the mass transfer rate cannot match the load change rate.

In the fuel cell stack or galvanostatic operation of a single cell, other cells with sufficient reactant or the single cell system would electrolyze the sick cell for the specified electron and proton or location of saturated fuel supply electrolyze sub-saturated area. There are three key points to define the sick fuel cell: (1) low electrode performance; (2) low fuel supply; (3) low air or oxygen supply. By filling the current requirements, the sick cell would be self-abandoned to conduct some different reaction under high potential, like carbon oxidation, water oxidation in an anode, or hydrogen evolution in a cathode [17]. Hydrogen evolution occurs in the cathode catalyst layer, close to the proton exchange membrane; hydrogen re-oxidization is in the other part of the cathode catalyst layer; and ORR occurs between the cathode catalyst layer and the cathode gas diffusion layer.

Sanyo Electronics previously studied the performance degradation of fuel cell caused by fuel starvation [19]. Then, Kim et al. [20] researched the effect of stoichiometry on the dynamic behavior of a PEMFC during load change, and found a vacuum effect in fuel starvation. Hydrogen utilization was significant to overshoot or undershoot behaviors. Taniguchi et al. [6] designed an experiment using a single cell to simulate cell reversal in a stack.

An abrupt change in oxygen demand at the cathode, like start-up operation, load change, or water management failure, would induce air starvation. Rao et al. [21] developed a distributed dynamic model including three layers (the gas flow channel, the diffusion layer, and the reaction layer) in a cathode to discuss the problem of gas starvation. There are many reports about current distribution and degradation caused by air starvation $[5,22,23]$. In these papers, current distribution is relevant to matter diffusion. The different reactant combinations in different layers have various reactant reaction modules. Due to reaction spontaneity and external drive, electron transfer and high potential occur at the same time.

All of the experiments reported above show that reactant starvation would change anode or cathode reaction conditions and lead to abnormal chemical reactions in high potential. These reasons would complicate the situation of the electrode surface. The following section will discuss in detail the specific situation, causes, and effects in view of a PEMFC anode and cathode.

\subsubsection{PEMFC Anode}

Compared to air starvation, complete hydrogen starvation will induce high potential to lead to carbon corrosion. Generally speaking, its impact on fuel cell is more far-reaching and thorough. So we pay more attention to cell reversal caused by hydrogen starvation.

In normal operations, excess hydrogen and air are supplied to the anode and cathode, respectively, whereby hydrogen and air distribution in the two compartments meet the mass transportation requirement. However, local fuel starvation induced by heterogeneous fuel distribution and complete fuel starvation in the whole anode have different effects in the whole anode. These two hydrogen-deficient conditions are similar but the damage to the fuel cell is completely different, and in fact heterogeneous fuel distribution cannot cause cell reversal but current reversal [24]. Local fuel starvation, or partial hydrogen coverage, damages the air electrode and induces oxygen migration across the membrane from the cathode $[25,26]$. There are two mathematical guides to help us 
distinguish between and get a clear picture of these two situations by demonstrating electron diffusion and gas flow.

Complete hydrogen starvation:

$$
N<I /(2 \mathrm{~F})
$$

Equation (1) depicts the practical status of fuel cell operations in the whole fuel starvation. In this equation, $N$ is the molar flow of hydrogen, $I$ is the practical current, and $\mathrm{F}$ is Faraday's constant. Without enough hydrogen to support the required current, the cell has to oxidize other cell system materials such as water and carbon at the fuel electrode to produce electrons and protons. Obviously, the fuel cell must be a single cell during galvanostatic operation or in a fuel cell stack where other cells have excess hydrogen supply.

Partial hydrogen coverage:

$$
N>I /(2 \mathrm{~F}) \text { but } \frac{I}{A}>I_{\text {lim }}
$$

Equation (2) shows the local hydrogen starvation. Here, $A$ is the active area and $I_{\text {lim }}$ is the limiting current density on active area. According to the equation, enough hydrogen is fed to the anode to satisfy the necessary current, but the fuel distribution is uneven in the gas distribution layer (GDL). Finally, the partial electrode area is not fed with adequate fuel. Oxygen in the cathode is permitted to migrate to the anode across the membrane to form the potential in some fuel-deficit areas to produce electrons, resulting in the average current value being higher than the limiting current. Some active areas have the same cell potential difference as a normal fuel cell, about $0.8 \mathrm{~V}$. Nevertheless, other negative regions' cell potential is lower than $0.8 \mathrm{~V}$ but more than 0 . This potential difference between the anode and cathode can be due to partial pressure discrepancy. So this situation cannot induce cell reversal but it will cause current reversal. Patterson and Darling studied the damage caused by local fuel starvation to the cathode catalyst [27]. The experiment showed that the situation of local fuel starvation is not similar to cell reversal caused by fuel starvation.

Only when the low hydrogen stoichiometry is less than 1 can the fuel cell polarity be reversed in the condition of a single-cell galvanostatic operation or a fuel cell stack where other cells have excess hydrogen supply. Obviously, all mechanisms and consequences of local fuel starvation would also occur at some location of the CL during overall fuel complete starvation [15]. In fact, the relationship between local fuel starvation and complete hydrogen starvation is just a qualitative change induced by a different hydrogen degree.

Different fuel flow fed to the anode provokes different phenomena on its electrode surface. Fuel starvation induced uneven currency diffusion, which had an increasing trend in the anode inlet and a decreasing trend in the outlet [4]; hydrogen oxidation reaction and water oxidation occurred at different regions of the electrode simultaneously. Due to the lack of hydrogen supply, which cannot satisfy the fuel cell system's electron requirements, the fuel cell system would spontaneously increase the anode potential as a result of an abnormal reaction or cell performance degradation, such as water oxidation, carbon corrosion, and so on, to obtain extra electrons [28]. In a galvanostatic operation or fuel cell stack, it will decompose the electrode material or the sick cell, like an electrolytic cell.

Therefore, in this condition, oxygen is simultaneously reduced in the cathode while oxygen is produced in the anode. The final consequence is that oxygen is pumped from cathode to anode while water moves in the opposite direction. The cell is similar to an "oxygen pump". We can use GC to test the anode production online [23]. The electrode half reactions and the overall reaction are listed below:

$$
\begin{gathered}
\text { Anode: } 2 \mathrm{H}_{2} \mathrm{O}(\mathrm{a}) \rightarrow \mathrm{O}_{2}(\mathrm{a})+4 \mathrm{H}^{+}+4 \mathrm{e}^{-} \\
\text {Cathode: } \mathrm{O}_{2}(\mathrm{c})+4 \mathrm{H}^{+}+4 \mathrm{e}^{-} \rightarrow 2 \mathrm{H}_{2} \mathrm{O} \text { (c) } \\
\text { Overall: } \mathrm{O}_{2} \text { (c) }+2 \mathrm{H}_{2} \mathrm{O}(\mathrm{a}) \rightarrow 2 \mathrm{H}_{2} \mathrm{O} \text { (c) }+\mathrm{O}_{2} \text { (a) }
\end{gathered}
$$


Water oxidation is the initial main reaction in a fuel cell, caused by fuel complete starvation in the anode. While the cell reversal experiment proceeds, the cell voltage becomes more and more negative. In Figure 1, we can see that the anode potential could be more than $1.5 \mathrm{~V}$ and the cathode is about $0.85 \mathrm{~V}$ at the first decreased stage. So the cell voltage is less than $-0.65 \mathrm{~V}$. At the next stage, the anode potential would become so high that carbon could be corroded gradually, especially with a platinum (Pt)-based catalyst, which would promote carbon corrosion. Finally, the cell voltage would get close to $-2.0 \mathrm{~V}$ until the fuel cell cannot function.

According to Equations (3), (10), and (11), corrosion in the anode, water oxidation, and carbon would produce heat to dehydrate the anode ionomer and membrane electrolyte. When the cell voltage reaches $-2.0 \mathrm{~V}$, the membrane would be completely degraded by dielectric breakdown [16]. We can judge which cell reversal strategy is best based on the time it takes the cell to reach $-2.0 \mathrm{~V}$ in order to avoid cell reversal causing irreversible damage. The better strategy should have a longer time to reach $-2.0 \mathrm{~V}$ of cell potential.

Aside from the cell polarity change, local current density and temperature also have special distribution across the $C L$ in cell reversal. Zhang and his team analyzed dynamically the local current densities and temperatures in proton exchange membrane fuel cells during reactant starvations [7]. The dynamic variations of local current densities with cell voltage and local temperatures during hydrogen starvation are studied. In this experiment, the hydrogen flow rate was held at $50 \mathrm{NmL} \cdot \mathrm{min}^{-1}$ (equal to average current density of $450 \mathrm{~mA} \cdot \mathrm{cm}^{-2}$ ). In the average current controlled operation, it was set to increase from 440 to $470 \mathrm{~mA} \cdot \mathrm{cm}^{-2}$ to mimic fuel starvation. We can see that at the initial stage in this experiment, about 10 to $20 \mathrm{~s}$, carbon corrosion is less than water oxidation, as indicated by a relatively stable current density variation. Then the local current densities began to diverge. The closer the location is to the anode inlet, the larger the current density. The outlet area had the completely opposite case. The local temperature variation was similar to local current density. Without a stable $-0.2 \mathrm{~V}$ cell voltage during fuel starvation [16,29], current density and temperature would be so divergent that the MEA would fail. The temperature and current density show a relatively clear picture to explain the electrode reaction.

In addition, cell reversal caused by hydrogen starvation would induce an abnormal oxidation reduction reaction at the electrode surface plane. There are different situations in different hydrogen feeding stoichiometry.

Akira Taniguchi et al. discussed and analyzed electrocatalyst degradation in PEMFC caused by cell reversal during fuel starvation [6]. The ruthenium dissolution occurred in the anode catalyst layer and the outlet had more severe degradation. There was also surface activity area loss in the cathode. The standard potential of transition metal couple is smaller than the electrode surface potential. Hence, some transition metal dissolution and redeposition are likely to occur. This is why the catalyst particle size becomes bigger than before cell reversal. In fuel starvation, the anode reaction is complex, involving hydrogen oxidation, water oxidation, carbon corrosion, and oxygen reduction. All of these reactions involve proton and electron transfer, which promote potential difference across the electrode plane. Reaction correspondence cannot be executed across the anode plane. It would simply get worse and worse until the system is dead.

Liang et al. focused their attention on a single cell under different degrees of fuel starvation [30]. They measured some electric parameters, such as cell voltage, current distribution, cathode and anode potentials, local interfacial potentials between anode and membrane, and so on, by means of a specially constructed segmented fuel cell. Experimental results showed that the current distribution was extremely uneven during fuel cell reversal, due to starvation or high local interfacial potential near the anode outlet. Hydrogen and water were oxidized at different areas of the anode. Anode carbon corrosion was proven to occur by monitoring its outlet's $\mathrm{CO}_{2}$ concentration. Figure 3 shows that the anode potential became higher and higher with the decrease of hydrogen stoichiometry, and water oxidation gradually took on an important role in the current contribution. Simultaneously, carbon corrosion was more and more serious than before. The comparison between cell reversal voltage 
and anode potential under different hydrogen conditions is shown in Table 1. Different hydrogen stoichiometry creates different terminal cell potential.

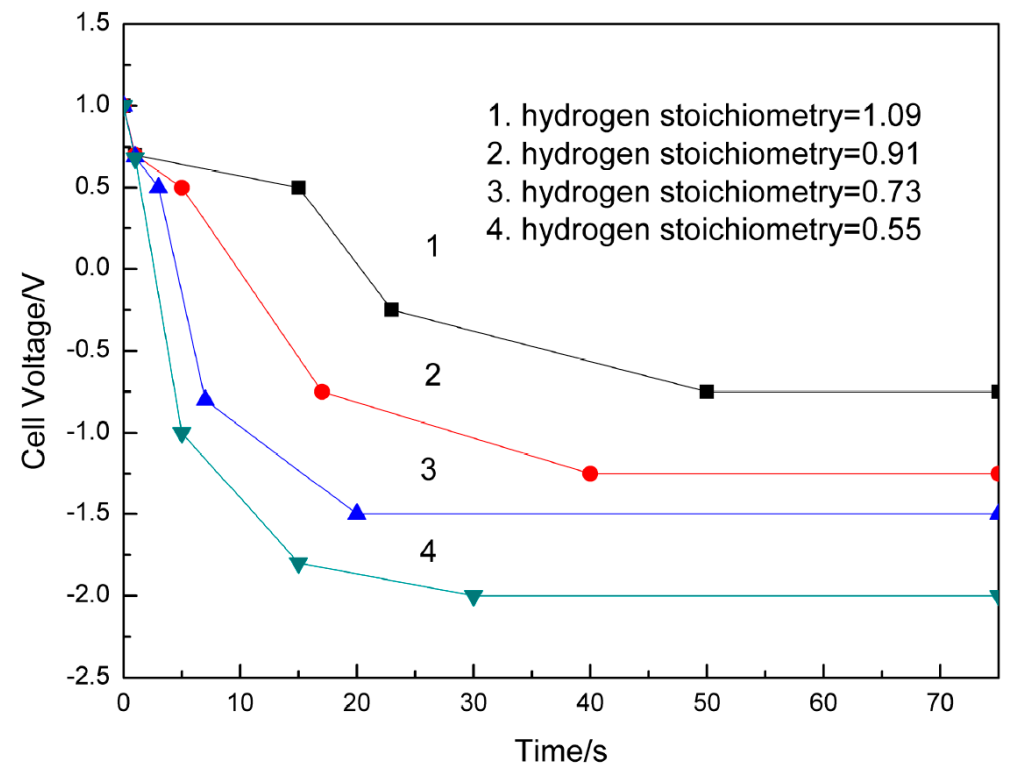

Figure 3. Changes of the anode potentials over time under different hydrogen stoichiometry. From 1 to 4 , hydrogen stoichiometry is $1.09,0.91,0.73$, and 0.55 , respectively. Reproduced with permission from [30]. Copyright Elsevier, 2009.

Table 1. Different times for cell reversal in different hydrogen stoichiometry.

\begin{tabular}{ccccc}
\hline $\begin{array}{c}\text { Hydrogen } \\
\text { Stoichiometry }\end{array}$ & $\begin{array}{c}\text { Time for Cell } \\
\text { Reversal (s) }\end{array}$ & $\begin{array}{c}\text { Cell Voltage } \\
(\mathbf{V})\end{array}$ & $\begin{array}{c}\text { Anode Potential } \\
\text { (V) }\end{array}$ & Reference \\
\hline 0.8 & Experiment started & About -0.7 & 1.3 & {$[6]$} \\
0.8 & About 300 & -2.0 & 2.5 & \\
\hline 1.09 & 26 & -0.718 & 0.955 & \\
0.91 & 10 & -1.125 & 1.313 & {$[30]$} \\
0.73 & 6 & -1.689 & 1.821 & \\
0.55 & 4 & -1.951 & 2.058 & \\
\hline
\end{tabular}

With the change of cell voltage over time, fuel cell system would begin to search reaction balance. In the anode, a compromise between hydrogen oxidation, water oxidation, and carbon corrosion move anode reaction from chaos to relative balance. Hydrogen stoichiometry has a different influence on the anode when it is lower than its satisfied supply. However, the experimental result is also affected by the fuel cell test device. Taniguchi's test result was not steady even $300 \mathrm{~s}$ after the experiment started, as compared to Liang's. It involves support material, test device design, sealing, and so on.

They also proposed that the hydrogen stoichiometry would shift the position of the lowest current [31]. With a comparatively high hydrogen feed, the position of the lowest current was closer to the anode outlet, where the fuel feed would encounter the gas drawn back from the outlet manifold and fuel starvation first occurred. The inadequate hydrogen supplied and "vacuum effect" would mix in the fuel cell. In this situation, researchers could analyze the area of fuel starvation in the anode according to the hydrogen stoichiometry to design a catalyst layer of anisotropy to avoid or mitigate the fuel starvation caused by inadequate fuel feed. 


\subsubsection{PEMFC Cathode}

When the real-time current exceeds the limiting current for ORR, air starvation occurs. In this case, the cathode voltage approaches the potential of reversible hydrogen due to the existence of hydrogen evolution. The potential of the cell is slightly negative in this condition, which is smaller than the hydrogen starvation. At this comparatively low potential value, it is hard to corrode carbon material.

In the PEMFC cathode, oxidation supply and the obstruction of gas channels caused by water flooding or freezing are the main causes of cell reversal. The causes also include control system failure and incorrect operation. Water flooding or ice would block the access of the reactant gases to the electrocatalyst surface and result in a slower mass transport rate compared to the oxygen reduction reaction and a relative absence of cathode reactant. There are three ways for the PEMFC cathode to generate excess water, i.e., humidified hydrogen and air to optimize the interaction between the interface and reactant, the reaction product in the cathode, and water migrating across the membrane by electro-osmotic drag with protons [5].

Combined with Figure 2, it is evident that the final cell voltage in cell reversal caused by air starvation was close to $-0.1 \mathrm{~V}$, which is much lower than the fuel starvation including anode and cathode voltage. Because potential is the driving force of electrochemical reaction, with high potential it is easier to realize carbon corrosion, catalyst metal dissolution, and sinter. Fuel starvation at the PEMFC anode results in irreversible damage to the PEMFC after several minutes under higher potential and is more critical than improper gas supply or distribution at the cathode [15].

When oxidation starvation happens, protons and electrons produced in the anode enter into the cathode. Simultaneously, hydrogen is consumed in the anode and produced in the cathode. Protons act as a "hydrogen pump" [23]. The electrode half reactions and the overall reaction are listed below:

$$
\begin{gathered}
\text { Anode: } \mathrm{H}_{2}(\mathrm{a}) \rightarrow 2 \mathrm{H}^{+}+2 \mathrm{e}^{-} \\
\text {Cathode: } 2 \mathrm{H}^{+}+2 \mathrm{e}^{-} \rightarrow \mathrm{H}_{2} \text { (c) } \\
\text { Overall: } \mathrm{H}_{2}(\mathrm{a}) \rightarrow \mathrm{H}_{2} \text { (c) }
\end{gathered}
$$

Regarding air starvation, researchers have focused on its causes, its dynamic characteristics across the anode plane, and the relationships between air feed and fuel cell degradation. Tüber et al. focused on the water flooding phenomenon at the fuel cell cathode caused by an accumulation of $\mathrm{H}_{2} \mathrm{O}$ [32]. They analyzed the effect of air flow, humidity, temperature, and flow-field type on flooding.

Zhang et al. also detected the dynamic characteristics of local current densities and temperatures in proton exchange membrane fuel cells during air starvation under current controlled and voltage controlled operation [7]. Their experimental results were obtained at different times and relative positions. This paper demonstrated that the local temperature changes followed the local current density changes during experimental operation. It is similar with hydrogen starvation. Due to reactant starvation, anode and cathode chemical reactions cannot follow normal operations. It refers that a mixture of gas evolution, reactant oxidation, and reduction reaction occur in anode or cathode. According to different reactions' energy change, there must be a relationship between electrode temperature and current density.

Taniguchi et al. researched degradation in PEMFC caused by cell reversal during air starvation [5]. They detected catalyst samples by means of cell reversal experiment and analyzed electrochemical performance, such as electrochemical surface area (ECSA) and current-potential character, using TEM images to illustrate that the size of catalyst particles increased, agglomerated, and recrystallized. Obviously, this degradation effect caused by air starvation was smaller than fuel starvation. It is shown in Figure 4 that ECSA shrinks as a function of time. In high electrode potential, it is easier to make catalyst particles dissolve and agglomerate. Similarly, it also will impact fuel cell durability and performance. Improving catalyst electrode surface diffusion is a feasible method to mitigate its sinter. 


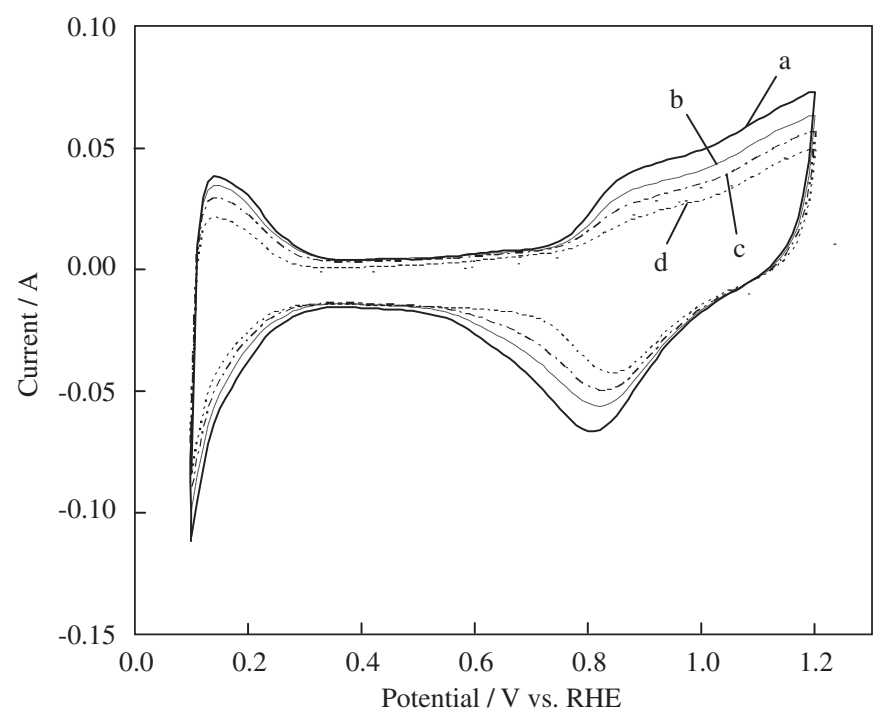

Figure 4. Change in the electrochemically active surface by a cell-reversal experiment: (a) before experiment; (b) after 5 min of experiment; (c) after $10 \mathrm{~min}$ of experiment; and (d) after $120 \mathrm{~min}$ of experiment. Reproduced with permission from [5]. Copyright Elsevier, 2008.

Natarajan et al. researched the relationship between cell temperature, anode and cathode gas streams humidity, and oxidant flow rate and current density distribution in a single-channel PEM fuel cell using a segmented collector setup [33]. The relationship between various oxidant flow rates and current densities in segment downstream was studied specifically. However, this setup also had its limitations in that this result did not include data from when the test temperature is over $55^{\circ} \mathrm{C}$. A local current density map at various test conditions is an accurate experimental measurement. With this method, we can analyze and understand the chemical reaction situation at the local electrode surface and the layer interface.

\subsection{Consequences of Cell Reversal}

There are some specific situations in anode and cathode above. Then, we put more attention on fuel starvation due to the permanent damage caused to the fuel cell. Hydrogen and air starvation are the main factors in cell reversal. Compared to air starvation, anode potential is increasing in fuel starvation. Once anode potential rises over $0.207 \mathrm{~V}$, or further to over $1.23 \mathrm{~V}$ with fuel consumption, water electrolysis and carbon oxidation would occur at the anode to provide the protons and electrons required for the load and the ORR at the cathode [16].

$$
\begin{gathered}
\text { Anode : } 2 \mathrm{H}_{2} \mathrm{O} \rightarrow \mathrm{O}_{2}+4 \mathrm{H}^{+}+4 \mathrm{e}^{-} E_{25}^{0}{ }^{\circ} \mathrm{C}=1.23 \mathrm{~V} \text { (vs. RHE) } \\
\text { Anode }: \mathrm{C}+2 \mathrm{H}_{2} \mathrm{O} \rightarrow \mathrm{CO}_{2}+4 \mathrm{H}^{+}+4 \mathrm{e}^{-} E_{25}^{0}{ }^{\circ} \mathrm{C}=0.21 \mathrm{~V} \text { (vs. RHE) }
\end{gathered}
$$

There are some other reactions happening under higher potential, like carbon reacting with water [34].

$$
\text { Anode : } \mathrm{C}+\mathrm{H}_{2} \mathrm{O} \rightarrow \mathrm{CO}+2 \mathrm{H}^{+}+2 \mathrm{e}^{-} E_{25}^{0}{ }^{\circ} \mathrm{C}=0.52 \mathrm{~V} \text { (vs. NHE) }
$$

As an indispensable component of the fuel cell system, carbon supports tend to corrode with water to produce $\mathrm{CO}_{2}$ at high potential [28]. Thanks to a large number of micropores, catalyst particles can be physically segregated by carbon supports to prevent particle sintering and catalyst dissolution, which can improve catalyst particles' specific surface area $[35,36]$. On the other hand, under cell reversal conditions, the advantages presented above would be reversed due to the degradation of the catalyst layer structure. Without integrated carbon support structure, three degradation effects would occur: (1) Pt particle agglomeration and particle growth; (2) Pt loss and redistribution; and (3) poisonous 
effects caused by contaminants [13]. Due to the inherent tendency of catalyst nanoparticles to agglomerate to reduce the surface energy, without the limit of support carbon it would promote deterioration of catalyst performance. Low catalyst performance would inhibit electron and proton production for the anode. With the low chemical reaction rate, the anode would only seize carbon and water as reactant material for ORR. This creates a vicious cycle that leads to fuel cell degradation and obsolescence. In the end, the fuel cell would be in a dynamic balance for several chemical reactions on the cathode and anode plane or interface.

However, in air starvation conditions, because of the lower anode and cathode potential, $0.05 \mathrm{~V}$ at anode and 0.85 or $0.05 \mathrm{~V}$ at cathode (localized ORR and HOR, respectively), carbon corrosion is unlikely to occur [24]. Instead, the mixture of oxygen and hydrogen may damage the fuel cell, due to the large hydrogen explosion ranging from $4 \%$ to $75.6 \%$ that is likely to occur at room temperature in a narrow and airtight space. Elsewhere, with the reduction of water and high cell voltage, the membrane would be completely degraded and broken apart. Air starvation does not have a direct or serious effect on electrodes compared to fuel starvation.

\section{Mitigation Strategies}

In the case of cell reversal, there are many approaches to attenuate or solve this question, such as system management and material modification. This review will discuss two ways to summarize cell reversal failures. System strategies mainly monitor operation parameters and feed it back by adjusting gas flow and load change, and controlling gas humidity and system temperature. Because the system management method should consider material features, we mainly pay attention to the role of electrode material and catalyst layer design. The quality and design of fuel cell installation are key to solving fuel cell system failure. Thus, in terms of materials, we focus on three parts: high performance catalysts, carbon support materials, and water oxidation reaction. Because the damage caused by air starvation is less than that caused by fuel starvation, we focus on the design and structure of the anode CL. For the cathode, researchers [37] adjusted the porosity of GDL to improve gas diffusion and changed the supported material to optimize the transformation of oxygen and water.

\subsection{System Management Strategies}

System management mitigates catalyst degradation by regulating fuel cell system operation parameters such as pressures, cell temperature, humidity levels, and current density [38]. With auxiliary equipment, researchers can detect reverse cell potential by monitoring cell voltages of individual cells or groups of cells in the stack [39]. Combined with current density distribution and temperature distribution detected by electrode segmentation technology [40], researchers can also understand the situation of cell starvation specifically. Furthermore, by setting an alarm value on the monitored cell voltage, the system can adjust operation parameters such as reactant flow rate, operation load, and water management data, and so on to avoid cell reversal or system halt situations. For instance, a sensor in the cell test system activates a switch that plays the role of removing the stack load the instant the sensor detects a precipitous loss of voltage [41].

Vahidi et al. proposed a fast-responding auxiliary power source to prevent oxygen starvation in a fuel cell during rapid current transitions [42]. In the oxidation starvation experiment of increasing stack power, the reactant starvation was less than $1 \%$ in the hybrid installation. An image of the hybrid installation follows. In the schematic, a capacitor was used to provide deficit current when the power sensor gives a signal. With capabilities of model predictive control, it can mitigate cell reversal damage in air starvation. However, it is transitory for fuel starvation to make carbon corrosion. This auxiliary installation cannot support adequate current in fuel starvation.

\subsection{System Material Modification}

Compared to the system management strategy, the design and composition of a fuel cell structure are more important, especially in terms of preventing cell reversal. While there are additional accessory 
costs, improving corrosion resistance naturally increases the fuel cell lifespan. Due to the high potential, slow reaction rate, and reactant transfer rate, which cannot meet current density in fuel cell stacks and in galvanostatic operations, researchers focused on the three aspects previously discussed-catalyst, carbon material, and water oxidation reaction.

Specifically, there are four approaches used to attenuate performance degradation and extend fuel cell lifespan $[11,15,37]$.

1. High catalyst activity and homogenous distribution;

2. Corrosion-resistant support material;

3. Water oxidation catalysts to promote water oxidation instead of carbon corrosion;

4. Increasing anode gas humidity.

\subsubsection{High-Performance Catalyst}

Low-performance catalysts would induce low anode and cathode reaction rates without sufficient protons and electrons supported in cell stacks and galvanostatic operations. However, in normal operation, Pt-based catalysts could meet the requirements of HOR and ORR due to their excellent catalyst performance [43].

Catalyst dissolution and agglomeration would occur via carbon support material corrosion [44], Pt loss [13,45], and surface energy reduction during standard fuel cell operations. Generally, the dissolution of $\mathrm{Pt}$ in the anode was more stable than in the cathode because of the electrode potential; the Pt particles' dissolution follows Equations (12) and (13) into $\mathrm{Pt}^{2+}$, and the standard equilibrium potential is $+0.88 \mathrm{~V}$ vs. RHE [46]. However, in cell reversal, the potential polarity is changed so that catalyst metals have high ORR potential with carbon support corrosion.

$$
\begin{gathered}
\mathrm{Pt}+\mathrm{H}_{2} \mathrm{O} \rightarrow \mathrm{PtO}+2 \mathrm{H}^{+}+2 \mathrm{e}^{-} \\
\mathrm{PtO}+2 \mathrm{H}^{+}+2 \mathrm{e}^{-} \leftrightarrow \mathrm{Pt}^{2+}+\mathrm{H}_{2} \mathrm{O}
\end{gathered}
$$

Pt-based catalyst dissolution is more common during cell reversal in the anode. According to the metal couple potential, different catalyst metal dissolution and redeposition occur. Furthermore, the catalyst particle size becomes bigger as a result of the electrochemical surface area decreasing. Then, it also would induce activity degradation and the potential would grow higher and higher. Obviously, this is another vicious cycle.

High durability and catalyst activity are the keys to solving this problem. Pt-alloy catalysts have better activity and stability compared to traditional $\mathrm{Pt} / \mathrm{C}$ catalysts, like $\mathrm{Pt}-\mathrm{Co}$ and $\mathrm{Pt}-\mathrm{Cr}-\mathrm{Ni}$ [47]. The different alloy elements and the larger size of catalyst particles show excellent properties [48]. With high catalyst activity to decrease ORR or HOR activity energy, the basic electrode reaction rate can occur even in poor operating conditions such as bad fuel or air transfer operation. As to the durability, the non-noble metals in the Pt alloy catalysts are more sensitive to the ionomer phase by XRD analysis. These non-noble metals can partially lose to induce (111) Pt skin to increase catalyst activity [49]. It indirectly improves fuel cell catalyst durability.

Various kinds of alloy metals have already proved to be capable in a fuel cell operating environment, including $\mathrm{Co}, \mathrm{Cr}, \mathrm{Fe}, \mathrm{Ni}$, and $\mathrm{V}$. Due to its advantage of stability, researchers paid more attention to $\mathrm{Pt}-\mathrm{Co} / \mathrm{C}$ recently [50,51]. Adzic et al. [52] showed that the durability of Pt-based catalyst could be improved with the addition of gold $(\mathrm{Au})$ clusters. The above reports showed that the $\mathrm{Pt}$ alloy could not only use a second metal to replace unavailable $\mathrm{Pt}$ to reduce costs, but also could use other metals to stabilize the Pt skin and frame structure to increase its lifespan. However, in cell reversal, catalyst performance only adds brilliance to its present splendor. Its root is reactant supply and material corrosion resistance. 


\subsubsection{Carbon Support Material}

As to material corrosion resistance, carbon is commonly used in PEMFC as a catalyst support, in GDLs, and as a bipolar-plate material [24]. Carbon support has many basic features, such as high specific surface area, good electrical conductivity, and chemical stability in a fuel cell system [53]. The stronger the interaction between carbon material and catalyst particles is, the better the performance of catalyst particles that is not prone to sinter is [36]. However, carbon oxidation reaction (COR) has a direct relationship with electrocatalytic material stability, and thermodynamically the reaction would happen at the cathode, because the reaction oxidation potential is $0.207 \mathrm{~V}$ (vs. RHE at $T=298 \mathrm{~K}$ ). In the case of cell reversal, high potential in both the anode and cathode could electrolyze carbon material. Furthermore, with the existence of Pt-based catalyst, carbon corrosion would be easier [10,54].

Different kinds of carbon material have an impact on corrosion resistance. As a new carbon material, graphene has special optical, chemical, and mechanical properties. Due to its high surface area, high conductivity, and unique graphitized basal plane structure, it has potential to serve as a fuel cell catalyst support material to overcome the problem of corrosion [55]. Considering the strong interaction between graphene and nanoparticles with functional groups, it is hard for Pt-based catalyst nanoparticles to dissolve or sinter [56]. Graphene increases a Pt-based catalyst metal's dissolution potential. Guo and Sun developed a facile solution-phase self-assembly method to deposit FePt NPs on a graphene surface [43]. This experiment mainly shows that graphene as a carbon support could have an effect on carbon corrosion in harsh conditions. Although graphene has influence on improving catalyst activity and durability, easily stacking between graphene sheets, the effects of surface functional groups should be intensively investigated.

Generally, graphitic content is a point to be researched. Luis Castanheira and coworkers proposed that the structure of carbon material, including high-surface area carbon (HSAC), Vulcan XC72, or reinforced-graphite (RG) with identical $\mathrm{Pt}(40 \mathrm{wt} \%)$, was the key to carbon corrosion caused by the hydrogen/air interface [10]. Results showed that there were $60 \%$ and $80 \%$ ECSA loss for Pt/Vulcan and $\mathrm{Pt} / \mathrm{HSAC}$, respectively. However, $\mathrm{Pt} / \mathrm{RG}$ only had $25 \%$. Compared to other disorganized carbon material, graphitic carbon is more robust against carbon corrosion.

Similarly, Artyushkova et al. [57,58] found a relationship between carbon material structure and chemical parameters. Good electrochemical activity of ORR but poor activity of COR were seen with high amounts of graphite carbon, small specific surface area, less carbon surface oxides, and many large-sized pores. In fact, it is a contradiction that graphite carbon has less surface deficit, which makes it resistant to corrosion, and has weak interaction with catalyst particles. ORR and COR should be in balance only if we consider carbon material surface factor. Carbon material surface structure and function can be a method of improving this situation. This paper [58] introduced the relationship between different carbon material structural features, corrosion resistance, and hydrophobicity or hydrophilicity. According to this relationship, we have a path to manufacture and synthesize ideal carbon material.

Carbon surface porosity plays a role in corrosion resistance and wettability. Wlodarczyk [59] suggested that carbon could show good corrosion resistance with a porosity value in excess of $10 \%$, because its wettability decreased with the value of porosity.

Apart from graphene, other carbon materials have also attracted researchers' attention. Oh et al. [60] focused on the performance of various carbon support materials including carbon black [44,61], carbon nanofiber [62,63], and carbon nanocage [64]. The electrochemical data about Pt-based catalyst supported by these three different types of carbon materials before and after corrosion are shown in Figure 5 and Table 2 [60]. Among these carbon materials, the amorphous carbon black was more susceptible to corrosion compared to carbon nanofiber (CNF) and carbon nanocage (CNC). In addition, $\mathrm{CNC}$ exhibited better performance than $\mathrm{CNF}$ in carbon corrosion resistance and preventing $\mathrm{Pt}$ particle aggregation, because of the balance between hydrophobicity and surface roughness [60]. Different three-dimensional carbon materials also lend corrosion resistance and physical segregation. 
By combining these two points-carbon surface and spatial structure, we can design the desired carbon material structure to optimize a fuel cell.

(a)

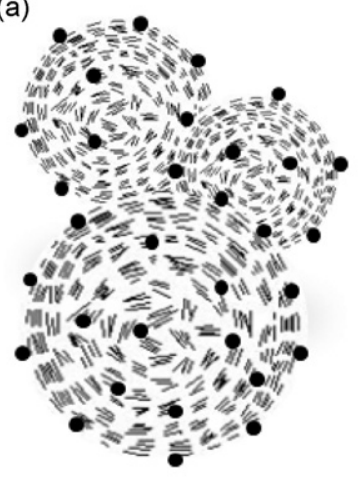

(b)

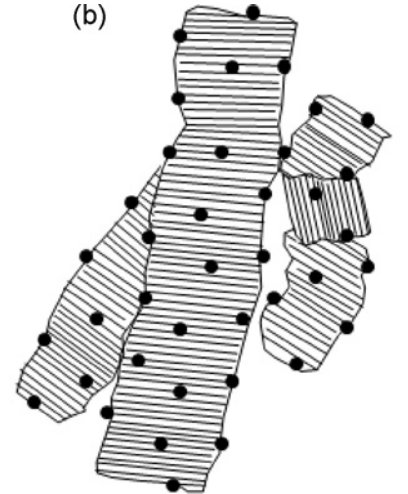

(c)

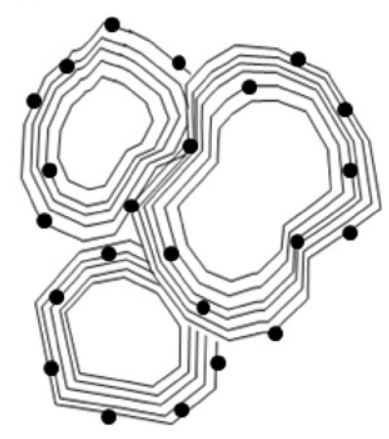

Figure 5. Three different types of carbon materials: (a) carbon black; (b) carbon nanofiber; (c) carbon nanocage. Reproduced with permission from [60]. Copyright Elsevier, 2009.

Table 2. Changes in different types of carbon materials' electrical data before and after corrosion experiments.

\begin{tabular}{|c|c|c|c|c|c|c|c|c|}
\hline \multirow{2}{*}{ Condition } & \multicolumn{2}{|c|}{$\begin{array}{l}\text { Active Surface } \\
\text { Area }\left(\mathrm{m}^{2} \cdot \mathrm{g}^{-1}\right)\end{array}$} & \multicolumn{2}{|c|}{$\begin{array}{l}\text { Membrane } \\
\text { Resistance }\end{array}$} & \multicolumn{2}{|c|}{$\begin{array}{c}\text { Charge Transfer } \\
\text { Resistance }\end{array}$} & \multirow{2}{*}{$\begin{array}{c}\mathrm{CO}_{2} \text { Emission } \\
(\mu \mathrm{L}) \\
30 \mathrm{~min} @ 1.4 \mathrm{~V}\end{array}$} & \multirow[t]{2}{*}{ Reference } \\
\hline & Before & After & Before & After & Before & After & & \\
\hline $\begin{array}{c}\mathrm{Pt} / \mathrm{XC}-72 \\
(1200 \text { cvcle) }\end{array}$ & 62.2 & 40.0 & - & - & - & - & - & {$[44]$} \\
\hline $\mathrm{Pt} / \mathrm{BP} 2000$ & 59.9 & 26.7 & - & - & - & - & - & - \\
\hline $\begin{array}{l}\text { Pt/Carbon Black } \\
\text { (up to } 4000 \text { cycle) }\end{array}$ & 41.7 & 15.2 & 0.016 & 0.025 & 0.039 & 0.328 & 651 & {$[60]$} \\
\hline $\mathrm{Pt} / \mathrm{CNF}$ & 30.1 & 27.7 & 0.016 & 0.016 & 0.054 & 0.058 & 49 & - \\
\hline $\mathrm{Pt} / \mathrm{CNC}$ & 33.6 & 32.9 & 0.016 & 0.016 & 0.04 & 0.041 & 4 & - \\
\hline
\end{tabular}

There are some specific examples to show various kinds of carbon material durability performance. Vinod et al. made an effort to test graphite carbon support [65]. In the accelerated stress test (AST), graphite $\mathrm{Pt} / \mathrm{C}$ catalyst had better carbon corrosion resistance relative to the untreated carbon sample. They tested ECSA, cell performance, charge transfer resistance by $\mathrm{CV}$, cell polarization, and resistance, respectively. In the PEMFC cathode, graphite $\mathrm{Pt} / \mathrm{C}$ catalyst electrical performance deteriorated by $10 \%$ after $70 \mathrm{~h}$ AST compared to $77 \%$ of untreated carbon support, as shown in Figure 6 [65].

Zhao et al. evaluated the change in nanostructure through the various heat treatments of carbon materials and their durability for the startup/shutdown operation of PEFC [66]. This paper had a similar result in that great catalyst support should have a high graphitization degree and good interaction with the catalyst. It gave an optimum heat treatment temperature of $1600{ }^{\circ} \mathrm{C}$ for best durability.

Generally, carbon material corrosion is caused by high electrode potential, which induces a reaction between carbon material and water. Carbon material surface defects are the most influential factor in corrosion. The purpose of carbon material graphite is to reduce surface defects for a more compact surface. Different types of carbon materials, like CNT, CNC, graphene, and so on, due to their unique surface structures, have different properties that have yet to be fully investigated. To achieve good ORR activity and carbon corrosion resistance, one must consider the balance between the graphitic level, the amount of surface oxide, surface roughness, pore size, and hydrophobicity. With the consideration of the important relationship among catalyst layer effective properties, ORR 
performance, and durability, it would prove useful to set design rules to produce and optimize the structure carbon material and MEA in order to satisfy various kinds of fuel cell operation conditions.
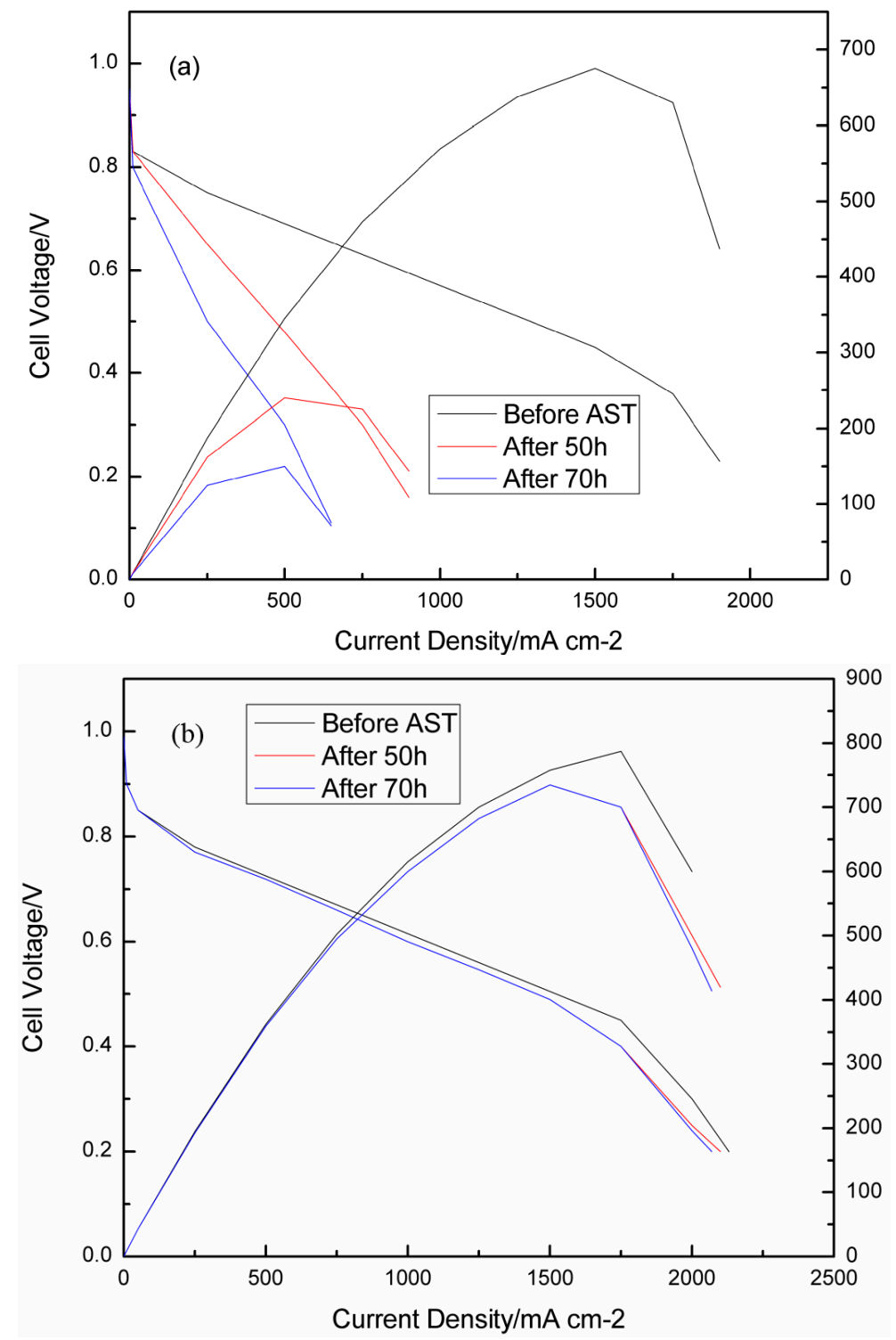

Figure 6. Steady-state performance curves for PEFCs with (a) Pt/Non-GrC and (b) Pt/GrC cathodes prior to AST and after 50 or $70 \mathrm{~h}$ of AST with $\mathrm{H}_{2}-\mathrm{O}_{2}$ at $60{ }^{\circ} \mathrm{C}$. Reproduced with permission from [65]. Copyright WILEY-VCH, 2011.

\subsubsection{Water Oxidation Reaction}

In fuel cell reversal, water oxidation occurs in combination with carbon corrosion among abnormal reactions. Like the sacrificial anode preventing metal corrosion, water oxidation would occur more prevalently to minimize carbon oxidation. Some papers [11,37] also propose that the promotion of water oxidation over carbon through anode structure and component modification would mitigate the catalyst degradation. Obviously, there are two kinds of approaches to promoting chemical reaction: (1) increasing the amount of reactant and (2) reducing water oxidation reaction's activation energy. In Equations (9) and (10), we can see that reducing the water oxidation reaction's over-potential and increasing its kinetic rate instead of the protons and electrons produced by carbon corrosion can protect the fuel cell system. These two methods are reported in detail as follows. 


\section{Water Oxidation Catalyst}

Catalysts can increase or decrease reaction activity energy to promote chemical reactions in directions we expect. Adding catalysts to boost water oxidation and reduce carbon corrosion would be an effective method of decreasing cell reversal.

Ralph et al. [16] added $20 \mathrm{wt} \% \mathrm{RuO}_{2}$ to $20 \% \mathrm{Pt}$ and $10 \% \mathrm{Ru}$ catalysts supported on Vulcan XC $72 \mathrm{R}$ with PTFE. The time to achieve $-2.0 \mathrm{~V}$ increased from 22 to $32 \mathrm{~min}$. As Table 3 shows, three water oxidation catalysts, $\mathrm{RuO}_{2}, \mathrm{RuO}_{2}-\mathrm{TiO}_{2}$, and $\mathrm{RuO}_{2}-\mathrm{IrO}_{2}$, had different effects on cell reversal with the increasing reactivity $\mathrm{RuO}_{2}-\mathrm{IrO}_{2}>\mathrm{RuO}_{2}-\mathrm{TiO}_{2}>\mathrm{RuO}_{2}$.

Table 3. The catalysts effect in anodes on the cell reversal tolerance in Step 3 of the protocol. Reproduced with permission from [16]. Copyright ECS, 2006.

\begin{tabular}{|c|c|}
\hline Anode Design with Different Catalyst & Time (min) \\
\hline $20 \% \mathrm{Pt}, 10 \% \mathrm{Ru} /$ Shawinigan anode catalyst & 0.25 \\
\hline Anode Catalyst* $+\mathrm{RuO}_{2} /$ Shawinigan & 4.5 \\
\hline Anode Catalyst ${ }^{*}+\mathrm{RuO}_{2}-\mathrm{TiO}_{2}(90: 10$ atomic ratio $\mathrm{Ru} / \mathrm{Ti}) /$ Shawinigan & 24 \\
\hline Anode Catalyst $* \mathrm{RuO}_{2}-\mathrm{IrO}_{2}(90: 10$ atomic ratio $\mathrm{Ru} / \mathrm{Ir}) /$ Shawinigan & 48 \\
\hline $20 \% \mathrm{Pt}, 10 \% \mathrm{Ru} /$ Shawinigan $+\mathrm{RuO}_{2}-\mathrm{IrO}_{2}(90: 10$ atomic ratio $\mathrm{Ru} / \mathrm{Ir})$ & 74 \\
\hline $40 \% \mathrm{Pt}, 20 \% \mathrm{Ru} /$ Shawinigan & 167 \\
\hline $40 \% \mathrm{Pt}, 20 \% \mathrm{Ru} /$ Shawinigan $+\mathrm{RuO}_{2}-\mathrm{IrO}_{2}(90: 10$ atomic ratio $\mathrm{Ru} / \mathrm{Ir}$ ) & 1630 \\
\hline
\end{tabular}

Ralph and coworkers made a series of investigations into electrochemical catalyst loading for water oxidation both unsupported and supported on various kinds of carbon materials. In the three-step protocol presented above, it is easy to recognize the performance of electrochemical catalysts according to the time it takes to get $-2.0 \mathrm{~V}$ of cell potential, as listed in Table 3 . The time to get to $-2.0 \mathrm{~V}$ can partially demonstrate the effect of a water oxidation catalyst. Combined with CV, TEM, or SEM imaging before and after cell reversal experiment, we can analyze the morphology of carbon support and catalyst particles generally.

Jang et al. [67] studied the effect of water oxidation catalyst added into cathode to weaken carbon corrosion. In Figure 7, compared with commercialized $\mathrm{Pt} / \mathrm{C}$ catalyst, the electrochemical carbon corrosion decreased by $76 \%$ with $2 \mathrm{wt} \% \mathrm{IrO}_{2}\left(0.016 \mathrm{mg} \cdot \mathrm{cm}^{-2}\right)$ under $1.6 \mathrm{~V}$ (vs. NHE) and $70{ }^{\circ} \mathrm{C} . \mathrm{CO}_{2}$ monitoring showed that the water oxidation catalyst had the effect of mitigating carbon corrosion. Carbon dioxide is produced by carbon corrosion in a fuel cell. The decrease of carbon dioxide production means the amount of COR is reducing. Theoretically, a water oxidation catalyst could also be used in anodes to decrease carbon corrosion.

Jang et al. [68] also studied the performance of $\mathrm{IrO}_{2}$ and $\mathrm{IrO}_{2} / \mathrm{C}$ mixed with $\mathrm{Pt} / \mathrm{C}$ on cathode durability during fuel starvation. In an accelerated fuel starvation test, with varying amounts of $\mathrm{IrO}_{2}(2.5,5,10$, or $20 \mathrm{wt} \%)$, the peak power densities of the cell cathode catalyst were decreased by $10.21 \%, 6.52 \%, 2.93 \%$, and almost 0 , respectively. This shows that $\mathrm{IrO}_{2}$ plays an important role in maintaining cell performance under extreme operation conditions. However, due to the screening effect, $\mathrm{IrO}_{2}$ particles in the cathode surface mixed with the commercial $\mathrm{Pt} / \mathrm{C}$ would reduce the activity of the Pt-based catalyst. Therefore, $\mathrm{IrO}_{2} / \mathrm{C}$ was chosen as the mixture of cathode catalyst. As a water electrolysis catalyst, with the $\mathrm{IrO}_{2} / \mathrm{C}$ increasing, the durability of the fuel cell became better and better due to the rapid decomposition of water molecules. According to the screening effect and catalyst durability, $10 \mathrm{wt} \% \mathrm{IrO}_{2} / \mathrm{C}$ with $\mathrm{Pt} / \mathrm{C}$ catalyst is a better choice.

In the case of water oxidation, the most important points are the design of catalyst layers mixed between Pt-based catalysts and water oxidation catalysts. Some papers $[16,67,68]$ proposed that the water oxidation catalyst has a positive effect on water electrolysis over and above carbon corrosion and the degradation of carbon support material. It is obvious that water oxidation catalyst improves the cell reversal tolerance with increasing effect $\left(\mathrm{RuO}_{2}-\mathrm{IrO}_{2}>\mathrm{RuO}_{2}-\mathrm{TiO}_{2}>\mathrm{RuO}_{2}\right)$. 


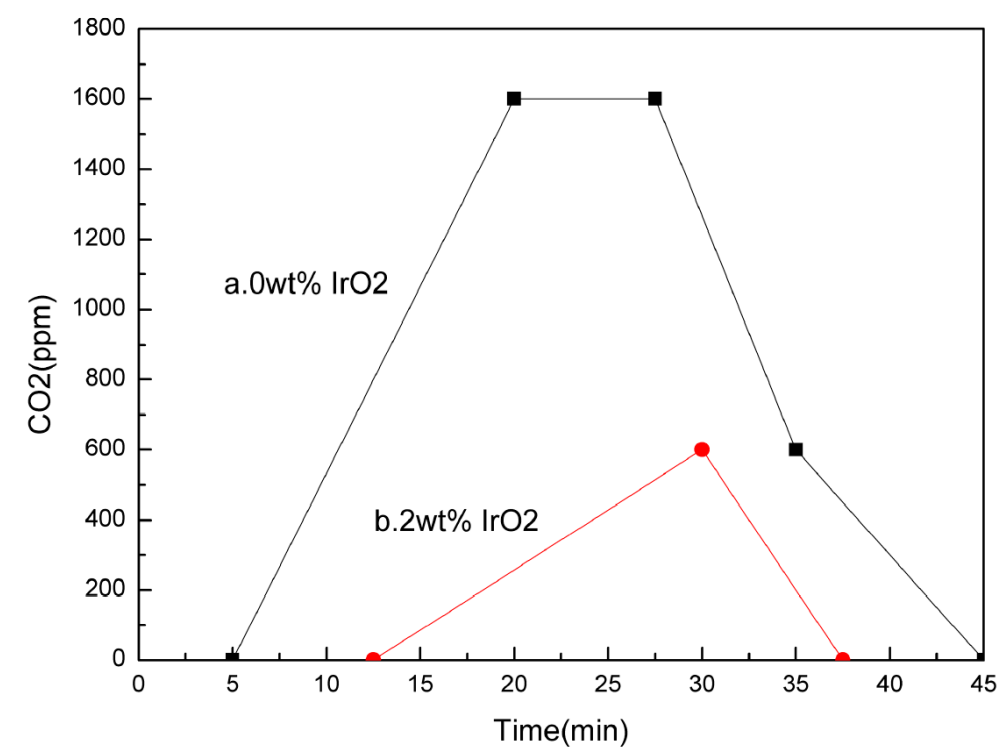

Figure 7. $\mathrm{MEA}-\mathrm{CO}_{2}$ mass spectrum (a) without $\mathrm{IrO}_{2}$; (b) with 2 wt $\% \mathrm{IrO}_{2}$. Reproduced with permission from [67]. Copyright American Chemical Society, 2010.

Control Humidity and Holding Water Volume

Enhancing water retention is another way to promote water oxidation over carbon corrosion, due to the increase of reactant resources. However, humidity has a negative relationship with fuel cell performance in some ranges. More does not mean better. Some patents and papers $[42,69,70]$ focused on cell reversal prevention over its performance and lifetime mitigation due to its irreversible damage. Therefore, a hydrophobic agent is a way to hold more water in the anode when cell reversal occurs induced by fuel starvation, which is always used in the gas diffusion layer to improve reactant gas diffusion and water management [71].

Ralph et al. [16] changed the water supply at the anode in their fuel cell reversal mimic experiment [72], in which the anode was fed with humidified $\mathrm{N}_{2}$ and the cathode fed with $\mathrm{O}_{2}$. When the cell current was set at $120 \mathrm{~A}$, the current density was $0.5 \mathrm{~A} \cdot \mathrm{cm}^{-2}$ and the cell potential was more than $-1.0 \mathrm{~V}$ (when the cell potential is less than $-2.0 \mathrm{~V}$, the polymer membrane can be completely degraded by dielectric breakdown). This experiment demonstrated that water supply played an important role in sustaining the cell potential and preventing MEA deterioration.

Besides increasing fuel humidity, the other method is to add hydrophobic materials into the catalyst layer, like PTFE. It could slow down the rate of water and increase the water contact angle by keeping water in the anode without shrinking the contact area between the catalyst layer and the membrane. Due to its key role in water retention, it is hoped that a hydrophobic agent would promote water oxidation reactions to solve the issues caused by cell reversal, resulting in less carbon component oxidation [16]. As Figure 8 depicted, Ralph et al. [16] put four Ballard cell stacks under cell reversal condition. When the cell potential got to $-2.0 \mathrm{~V}$, the one added PTFE was increased to 22 from $3 \mathrm{~min}$, which is the time the standard anode took. 


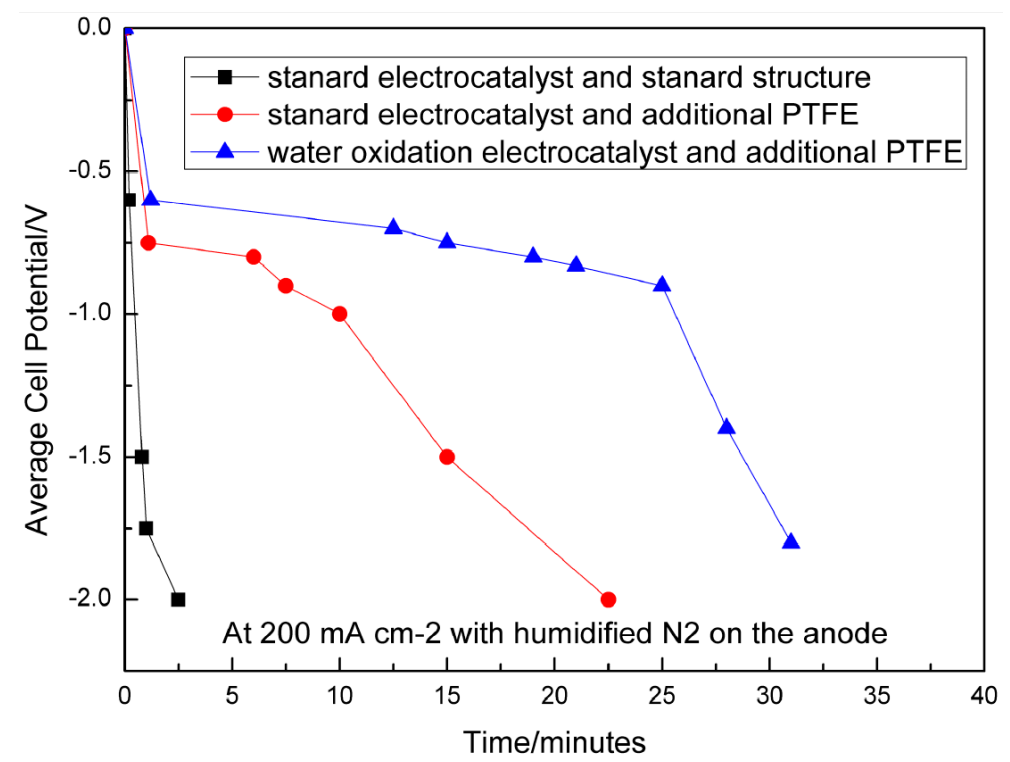

Figure 8. The effect of anode catalyst layer structure and composition in Ballard four-cell stack tests. Reproduced with permission from [16]. Copyright ECS, 2006. The anode contains $20 \mathrm{wt} \% \mathrm{Pt}$ and $10 \mathrm{wt} \% \mathrm{Ru}$ supported on Vulcan XC72R at an electrode loading rate of ca. $0.3 \mathrm{mg} \cdot \mathrm{Pt} \cdot \mathrm{cm}^{-2}$ with the water oxidation electrocatalyst added at a loading rate of ca. $0.1 \mathrm{mg} \cdot \mathrm{Ru} \cdot \mathrm{cm}^{-2}$.

Numerous research papers have studied the effect of hydrophobic agent content and species, including polytetrafluoroethylene (PTFE), polyvinylidene fluoride (PVDF), and fluorinated ethylene propylene (FEP), in GDL on the performance of fuel cells [73-75]. Given their excellent characteristics, hydrophobic agents can be used in the anode catalyst layer to hold more water.

\section{Conclusions}

Fuel starvation, inadequate air supply, water flooding, load change, low catalyst performance, etc. can induce cell reversal when the current rate exceeds the limiting mass transfer rate. Because these factors cannot produce sufficient electron and proton feeds to match current stack requirements and achieve current value balance, the fuel cell voltage could reverse and some other abnormal chemical reactions might occur to make up for the deficit. In these abnormal operating conditions, there is irreversible damage to the PEMFC system, including carbon support corrosion, catalyst and sinter agglomeration, and membrane degradation. In fact, gross fuel starvation is different from localized fuel starvation in terms of causes, carbon corrosion area, cell voltage, and current phenomena. Generally, cell reversal caused by overall fuel starvation is more critical than in a cathode and is induced by improper gas supply, flooding, and any other factors that obstruct the flow field and catalyst layer; therefore, the design of the anode catalyst layer and the catalytic performance have drawn more attention to cell reversal. Due to the existence of hydrogen in cathodes or oxygen in anodes, cell reversal can cause permanent damage to a fuel cell.

To solve this problem or mitigate the harm to fuel cells, two approaches have been used in recent years. First is the system management strategy, where auxiliary monitoring equipment is used to determine necessary adjustments to operation parameters to avoid cell reversal, such as adding reactant flow rate, change operation load, water management, and so on. The second is system material modification to resist cell reversal. Specifically, there are three approaches to attenuate performance loss and extend fuel cell lifespan. Researchers have placed attention on high-performance catalysts, carbon support materials, and water oxidation reactions. In addition, heat-resistant membranes also attract more attention for their ability to reduce water flooding in a cathode, but they would decrease the proton transfer rate and catalyst efficiency. 
Obviously, there are still several problems in need of further study, such as (1) understanding the effects of different types of carbon materials' surface forms and structure; (2) developing a novel catalyst layer assembly including a high-performance catalyst, corrosion-resistant carbon material, a water oxidation catalyst, and hydrophobic agents; and (3) distinguishing the specific electrode reaction caused by the phenomenon of hydrogen pump and oxygen pump. Compared to a fuel cell system of water and heat management, this is simpler and more critical to catalyst layer design, and would make system management more efficient by diminishing several controlling limitations.

Acknowledgments: This paper was generously supported by the National Natural Science Foundation (No. 21206128).

Author Contributions: Daijun Yang, Bing Li, and Cunman Zhang collected experiment data, analyzed and synthesized fuel cell theory, Jue Wang and Bing Li revised the English expression. Congwei Qin analyzed references material, experiment data and wrote the paper.

Conflicts of Interest: The authors declare no conflict of interest.

\section{References}

1. Yi, B. Fuel Cell-Principle, Technology and Application; Chemical Industry: Beijing, China, 2003; p. 41.

2. Rajashekara, K.; Rathore, A.K. Power conversion and control for fuel cell systems in transportation and stationary power generation. Electr. Power Compon. Syst. 2015, 43, 1376-1387. [CrossRef]

3. Popovich, N. US Department of Energy Hydrogen and Fuel Cells Program 2015 Annual Merit Review and Peer Evaluation Report: June 8-12, 2015, Arlington, Virginia; NREL (National Renewable Energy Laboratory (NREL): Golden, CO, USA, 2015.

4. Zhou, F.; Andreasen, S.J.; Kær, S.K. Experimental study of cell reversal of a high temperature polymer electrolyte membrane fuel cell caused by $\mathrm{H}_{2}$ starvation. Int. J. Hydrogen Energy 2015, 40, 6672-6680. [CrossRef]

5. Taniguchi, A.; Akita, T.; Yasuda, K.; Miyazaki, Y. Analysis of degradation in PEMFC caused by cell reversal during air starvation. Int. J. Hydrogen Energy 2008, 33, 2323-2329. [CrossRef]

6. Taniguchi, A.; Akita, T.; Yasuda, K.; Miyazaki, Y. Analysis of electrocatalyst degradation in PEMFC caused by cell reversal during fuel starvation. J. Power Sources 2004, 130, 42-49. [CrossRef]

7. Zhang, G.; Shen, S.; Guo, L.; Liu, H. Dynamic characteristics of local current densities and temperatures in proton exchange membrane fuel cells during reactant starvations. Int. J. Hydrogen Energy 2012, 37, 1884-1892. [CrossRef]

8. Yu, Y.; Li, H.; Wang, H.; Yuan, X.-Z.; Wang, G.; Pan, M. A review on performance degradation of proton exchange membrane fuel cells during startup and shutdown processes: Causes, consequences, and mitigation strategies. J. Power Sources 2012, 205, 10-23. [CrossRef]

9. Dou, M.; Hou, M.; Liang, D.; Shen, Q.; Zhang, H.; Lu, W.; Shao, Z.; Yi, B. Behaviors of proton exchange membrane fuel cells under oxidant starvation. J. Power Sources 2011, 196, 2759-2762. [CrossRef]

10. Castanheira, L.; Silva, W.O.; Lima, F.H.; Crisci, A.; Dubau, L.; Maillard, F.D.R. Carbon corrosion in proton-exchange membrane fuel cells: Effect of the carbon structure, the degradation protocol, and the gas atmosphere. ACS Catal. 2015, 5, 2184-2194. [CrossRef]

11. Knights, S.D.; Colbow, K.M.; St-Pierre, J.; Wilkinson, D.P. Aging mechanisms and lifetime of PEFC and DMFC. J. Power Sources 2004, 127, 127-134. [CrossRef]

12. Zhou, F.; Andreasen, S.J.; Kær, S.K.; Yu, D. Analysis of accelerated degradation of a HT-PEM fuel cell caused by cell reversal in fuel starvation condition. Int. J. Hydrogen Energy 2015, 40, 2833-2839. [CrossRef]

13. Zhang, S.; Yuan, X.-Z.; Hin, J.N.C.; Wang, H.; Friedrich, K.A.; Schulze, M. A review of platinum-based catalyst layer degradation in proton exchange membrane fuel cells. J. Power Sources 2009, 194, 588-600. [CrossRef]

14. Kang, J.; Jung, D.W.; Park, S.; Lee, J.-H.; Ko, J.; Kim, J. Accelerated test analysis of reversal potential caused by fuel starvation during PEMFCs operation. Int. J. Hydrogen Energy 2010, 35, 3727-3735. [CrossRef]

15. Yousfi-Steiner, N.; Moçotéguy, P.; Candusso, D.; Hissel, D. A review on polymer electrolyte membrane fuel cell catalyst degradation and starvation issues: Causes, consequences and diagnostic for mitigation. J. Power Sources 2009, 194, 130-145. [CrossRef] 
16. Ralph, T.R.; Hudson, S.; Wilkinson, D.P. Electrocatalyst stability in PEMFCs and the role of fuel starvation and cell reversal tolerant anodes. ECS Trans. 2006, 1, 67-84.

17. Yang, X.-G.; Ye, Q.; Cheng, P. Hydrogen pumping effect induced by fuel starvation in a single cell of a PEM fuel cell stack at galvanostatic operation. Int. J. Hydrogen Energy 2012, 37, 14439-14453. [CrossRef]

18. Li, B.; Higgins, D.C.; Xiao, Q.; Yang, D.; Zhng, C.; Cai, M.; Chen, Z.; Ma, J. The durability of carbon supported Pt nanowire as novel cathode catalyst for a 1.5 kW PEMFC stack. Appl. Catal. B 2015, 162, 133-140. [CrossRef]

19. Sakamoto, S.; Karakane, M.; Maeda, H.; Miyake, Y.; Susai, T.; Isono, T. Study of the Factors Affecting PEFC Life Characteristic; Ecology and Energy Systems Research Center, SANYO Electric Co., Ltd.: Tochigi, Japan, 2000; pp. 326-8534.

20. Kim, S.; Shimpalee, S.; van Zee, J. The effect of stoichiometry on dynamic behavior of a proton exchange membrane fuel cell (PEMFC) during load change. J. Power Sources 2004, 135, 110-121. [CrossRef]

21. Rao, R.M.; Rengaswamy, R. A distributed dynamic model for chronoamperometry, chronopotentiometry and gas starvation studies in PEM fuel cell cathode. Chem. Eng. Sci. 2006, 61, 7393-7409.

22. Shen, Q.; Hou, M.; Yan, X.; Liang, D.; Zang, Z.; Hao, L.; Shao, Z.; Hou, Z.; Ming, P.; Yi, B. The voltage characteristics of proton exchange membrane fuel cell (PEMFC) under steady and transient states. J. Power Sources 2008, 179, 292-296. [CrossRef]

23. Liu, Z.; Yang, L.; Mao, Z.; Zhuge, W.; Zhang, Y.; Wang, L. Behavior of PEMFC in starvation. J. Power Sources 2006, 157, 166-176. [CrossRef]

24. Büchi, F.N.; Inaba, M.; Schmidt, T.J. Polymer Electrolyte Fuel Cell Durability; Springer: New York, NY, USA, 2009.

25. Ofstad, A.; Davey, J.; Sunde, S.; Borup, R.L. Carbon corrosion of a PEMFC during shut-down/start-up when using an air purge procedure. ECS Trans. 2008, 16, 1301-1311.

26. Hu, J.; Sui, P.; Kumar, S.; Djilali, N. Modelling and simulations of carbon corrosion during operation of a polymer electrolyte membrane fuel cell. Electrochim. Acta 2009, 54, 5583-5592. [CrossRef]

27. Patterson, T.W.; Darling, R.M. Damage to the cathode catalyst of a PEM fuel cell caused by localized fuel starvation. Electrochem. Solid-State Lett. 2006, 9, A183-A185. [CrossRef]

28. Lim, K.H.; Oh, H.-S.; Jang, S.-E.; Ko, Y.-J.; Kim, H.-J.; Kim, H. Effect of operating conditions on carbon corrosion in polymer electrolyte membrane fuel cells. J. Power Sources 2009, 193, 575-579. [CrossRef]

29. Ralph, T.; Hogarth, M. Catalysis for low temperature fuel cells. Platin. Met. Rev. 2002, 46, 117-135.

30. Liang, D.; Shen, Q.; Hou, M.; Shao, Z.; Yi, B. Study of the cell reversal process of large area proton exchange membrane fuel cells under fuel starvation. J. Power Sources 2009, 194, 847-853. [CrossRef]

31. Liang, D.; Dou, M.; Hou, M.; Shen, Q.; Shao, Z.; Yi, B. Behavior of a unit proton exchange membrane fuel cell in a stack under fuel starvation. J. Power Sources 2011, 196, 5595-5598. [CrossRef]

32. Tüber, K.; Pócza, D.; Hebling, C. Visualization of water buildup in the cathode of a transparent PEM fuel cell. J. Power Sources 2003, 124, 403-414. [CrossRef]

33. Natarajan, D.; van Nguyen, T. Current distribution in PEM fuel cells. Part 2: Air operation and temperature effect. AIChE J. 2005, 51, 2599-2608. [CrossRef]

34. Rangel, C.; Travassos, M.A.; Fernandes, V.R.; Silva, R.; Paiva, T. Fuel Starvation: Irreversible Degradation Mechanisms in PEM Fuel Cells; WHEC—World Hydrogen Energy Convention: Essen, Germany, 2010.

35. Zhang, J.; Yang, H.; Fang, J.; Zou, S. Synthesis and oxygen reduction activity of shape-controlled $\mathrm{Pt}_{3} \mathrm{Ni}^{\mathrm{N}}$ nanopolyhedra. Nano Lett. 2010, 10, 638-644. [CrossRef] [PubMed]

36. Yu, X.; Ye, S. Recent advances in activity and durability enhancement of Pt/C catalytic cathode in PEMFC: Part II: Degradation mechanism and durability enhancement of carbon supported platinum catalyst. J. Power Sources 2007, 172, 145-154. [CrossRef]

37. Wilkinson, D.; St-Pierre, J.; Vielstich, W.; Gasteiger, H.; Lamm, A. Handbook of fuel cells—Fundamentals, technology and applications. Fuel Cell Technol. Appl. 2003, 3, 611.

38. Maass, S.; Finsterwalder, F.; Frank, G.; Hartmann, R.; Merten, C. Carbon support oxidation in PEM fuel cell cathodes. J. Power Sources 2008, 176, 444-451. [CrossRef]

39. Barton, R.H. Preventing Voltage Reversal Conditions in Solid Polymer Electrolyte Cells; Heating Resistor and Rectifier in Series; Sensing Thermistor; Detecting a Low Voltage in a Fuel Cell. U.S. Patent 6,724,194, 20 April 2004.

40. Baumgartner, W.; Parz, P.; Fraser, S.; Wallnöfer, E.; Hacker, V. Polarization study of a PEMFC with four reference electrodes at hydrogen starvation conditions. J. Power Sources 2008, 182, 413-421. [CrossRef] 
41. Perry, M.L.; Patterson, T.; Reiser, C. Systems strategies to mitigate carbon corrosion in fuel cells. ECS Trans. 2006, 3, 783-795.

42. Vahidi, A.; Stefanopoulou, A.; Peng, H. Model predictive control for starvation prevention in a hybrid fuel cell system. In Proceedings of the 2004 American Control Conference, 30 June-2 July 2004; IEEE: Boston, MA, USA; pp. 834-839.

43. Jung, N.; Chung, D.Y.; Ryu, J.; Yoo, S.J.; Sung, Y.-E. Pt-based nanoarchitecture and catalyst design for fuel cell applications. Nano Today 2014, 9, 433-456. [CrossRef]

44. Wang, J.; Yin, G.; Shao, Y.; Zhang, S.; Wang, Z.; Gao, Y. Effect of carbon black support corrosion on the durability of Pt/C catalyst. J. Power Sources 2007, 171, 331-339. [CrossRef]

45. Luo, Z.; Li, D.; Tang, H.; Pan, M.; Ruan, R. Degradation behavior of membrane-electrode-assembly materials in 10-cell PEMFC stack. Int. J. Hydrogen Energy 2006, 31, 1831-1837. [CrossRef]

46. Yoda, T.; Uchida, H.; Watanabe, M. Effects of operating potential and temperature on degradation of electrocatalyst layer for PEFCs. Electrochim. Acta 2007, 52, 5997-6005. [CrossRef]

47. Colón-Mercado, H.R.; Popov, B.N. Stability of platinum based alloy cathode catalysts in PEM fuel cells. J. Power Sources 2006, 155, 253-263. [CrossRef]

48. Gasteiger, H.A.; Kocha, S.S.; Sompalli, B.; Wagner, F.T. Activity benchmarks and requirements for Pt, Pt-alloy, and non-Pt oxygen reduction catalysts for PEMFCs. Appl. Catal. B 2005, 56, 9-35. [CrossRef]

49. Wan, L.J.; Moriyama, T.; Ito, M.; Uchida, H.; Watanabe, M. In situ STM imaging of surface dissolution and rearrangement of a Pt-Fe alloy electrocatalyst in electrolyte solution. Chem. Commun. 2002. [CrossRef]

50. Paulus, U.; Wokaun, A.; Scherer, G.; Schmidt, T.; Stamenkovic, V.; Radmilovic, V.; Markovic, N.; Ross, P. Oxygen reduction on carbon-supported Pt-Ni and Pt-Co alloy catalysts. J. Phys. Chem. B 2002, 106, 4181-4191. [CrossRef]

51. Yu, P.; Pemberton, M.; Plasse, P. PtCo/C cathode catalyst for improved durability in PEMFCs. J. Power Sources 2005, 144, 11-20. [CrossRef]

52. Zhang, J.; Sasaki, K.; Sutter, E.; Adzic, R. Stabilization of platinum oxygen-reduction electrocatalysts using gold clusters. Science 2007, 315, 220-222. [CrossRef] [PubMed]

53. Stevens, D.; Hicks, M.; Haugen, G.; Dahn, J. Ex situ and in situ stability studies of PEMFC catalysts effect of carbon type and humidification on degradation of the carbon. J. Electrochem. Soc. 2005, 152, A2309-A2315. [CrossRef]

54. Kim, M.; Jung, N.; Eom, K.; Yoo, S.J.; Kim, J.Y.; Jang, J.H.; Kim, H.-J.; Hong, B.K.; Cho, E. Effects of anode flooding on the performance degradation of polymer electrolyte membrane fuel cells. J. Power Sources 2014, 266, 332-340. [CrossRef]

55. Antolini, E. Graphene as a new carbon support for low-temperature fuel cell catalysts. Appl. Catal. B 2012, 123, 52-68. [CrossRef]

56. Guo, S.; Sun, S. FePt nanoparticles assembled on graphene as enhanced catalyst for oxygen reduction reaction. J. Am. Chem. Soc. 2012, 134, 2492-2495. [CrossRef] [PubMed]

57. Artyushkova, K.; Atanassov, P.; Dutta, M.; Wessel, S.; Colbow, V. Structural correlations: Design levers for performance and durability of catalyst layers. J. Power Sources 2015, 284, 631-641. [CrossRef]

58. Artyushkova, K.; Pylypenko, S.; Dowlapalli, M.; Atanassov, P. Structure-to-property relationships in fuel cell catalyst supports: Correlation of surface chemistry and morphology with oxidation resistance of carbon blacks. J. Power Sources 2012, 214, 303-313. [CrossRef]

59. Wlodarczyk, R. Porous carbon materials for elements in low-temperature fuel cells. Arch. Metall. Mater. 2015, 60, 117-120. [CrossRef]

60. Oh, H.-S.; Lim, K.H.; Roh, B.; Hwang, I.; Kim, H. Corrosion resistance and sintering effect of carbon supports in polymer electrolyte membrane fuel cells. Electrochim. Acta 2009, 54, 6515-6521. [CrossRef]

61. Dicks, A.L. The role of carbon in fuel cells. J. Power Sources 2006, 156, 128-141.

62. Yang, W.; Wang, Y.; Li, J.; Yang, X. Polymer wrapping technique: An effective route to prepare Pt nanoflower/carbon nanotube hybrids and application in oxygen reduction. Energy Environ. Sci. 2010, 3, 144-149. [CrossRef]

63. Oh, H.S.; Kim, H. Efficient synthesis of Pt nanoparticles supported on hydrophobic graphitized carbon nanofibers for electrocatalysts using noncovalent functionalization. Adv. Funct. Mater. 2011, 21, 3954-3960. [CrossRef] 
64. Lim, K.H.; Oh, H.-S.; Kim, H. Use of a carbon nanocage as a catalyst support in polymer electrolyte membrane fuel cells. Electrochem. Commun. 2009, 11, 1131-1134. [CrossRef]

65. Vinod Selvaganesh, S.; Selvarani, G.; Sridhar, P.; Pitchumani, S.; Shukla, A. Graphitic carbon as durable cathode-catalyst support for PEFCs. Fuel Cells 2011, 11, 372-384. [CrossRef]

66. Zhao, X.; Hayashi, A.; Noda, Z.; Kimijima, K.i.; Yagi, I.; Sasaki, K. Evaluation of change in nanostructure through the heat treatment of carbon materials and their durability for the start/stop operation of polymer electrolyte fuel cells. Electrochim. Acta 2013, 97, 33-41. [CrossRef]

67. Jang, S.-E.; Kim, H. Effect of water electrolysis catalysts on carbon corrosion in polymer electrolyte membrane fuel cells. J. Am. Chem. Soc. 2010, 132, 14700-14701. [CrossRef] [PubMed]

68. Jang, I.; Hwang, I.; Tak, Y. Attenuated degradation of a PEMFC cathode during fuel starvation by using carbon-supported $\mathrm{IrO}_{2}$. Electrochim. Acta 2013, 90, 148-156. [CrossRef]

69. Reiser, C.A. Preventing Fuel Starvation of a Fuel Cell Stack. U.S. Patent 7,807,302, 5 October 2010.

70. Wilkinson, D.P.; Chow, C.Y.; Allan, D.E.; Johannes, E.P.; Roberts, J.A.; St-Pierre, J.; Longley, C.J.; Chan, J.K. Method and Apparatus for Operating an Electrochemical Fuel Cell with Periodic Fuel Starvation at the Anode. U.S. Patent 6,096,448, 1 August 2000.

71. Park, S.; Lee, J.-W.; Popov, B.N. A review of gas diffusion layer in PEM fuel cells: Materials and designs. Int. J. Hydrogen Energy 2012, 37, 5850-5865. [CrossRef]

72. Knights, S.D.; Taylor, J.L.; Wilkinson, D.P.; Wainwright, D.S. Fuel Cell Anode Structures for Voltage Reversal Tolerance. U.S. Patent 6,517,962, 11 February 2003.

73. Lim, C.; Wang, C. Effects of hydrophobic polymer content in GDL on power performance of a PEM fuel cell. Electrochim. Acta 2004, 49, 4149-4156. [CrossRef]

74. Park, S.; Popov, B.N. Effect of hydrophobicity and pore geometry in cathode GDL on PEM fuel cell performance. Electrochim. Acta 2009, 54, 3473-3479. [CrossRef]

75. Ismail, M.; Hughes, K.; Ingham, D.; Ma, L.; Pourkashanian, M. Effect of PtFe loading of gas diffusion layers on the performance of proton exchange membrane fuel cells running at high-efficiency operating conditions. Int. J. Energy Res. 2013, 37, 1592-1599. [CrossRef]

(C) 2016 by the authors; licensee MDPI, Basel, Switzerland. This article is an open access article distributed under the terms and conditions of the Creative Commons Attribution (CC-BY) license (http://creativecommons.org/licenses/by/4.0/). 